\title{
GUNVOR CHRISTENSEN
}

\section{KØBENHAVN}

\begin{abstract}
'Into the Labyrinth' [...] fitted precisely into my aimless, desperate walks and rides round London's streets, squares and inner suburbs (and) the adventures and sufferings attendant upon her sexual initiation took place in the bedrooms, hotels, the theatres and cafés of a great city - a city like a magic set of boxes, with, inside each box, a yet smaller and more secret one (Wilson 1991:3).
\end{abstract}

Byen og seksualitet kædes sammen i ovenstående citat af Elizabeth Wilson. Hun beskriver byens organisering, herunder den seksuelle organisering, som en labyrint, vi hele tiden kan bevæge os længere og dybere ind i. Vi kan udforske labyrintens muligheder og begrænsninger, og vi kan gøre os erfaringer med at finde vores favoritsteder og rum for at udfolde vores seksuelle længsler og fantasier. Byen er at sammenligne med et seksuelt reservoir, hvori vi kan udfolde vores seksualitet. Denne udfoldelse er en mulighed, der opstår i byens menneskemængde, fordi vi i den kan udføre seksuelle og erotiske handlinger med anonyme fremmede og ikke kun med partneren i kærlighed (Wilson 1987:143). Denne mulighed har Henning Bech også identificeret. Han fremhæver, at mandlige homoseksuelle i årevis har benyttet sig af bylivets mulighed, og at det at indgå i uforpligtende, anonyme og segmenterede sexrelationer har etableret sig som en livsstil. Det er en livsstil, der tidligere har mødt samfundets modstand. Den har været betragtet som „farlig“" og problematisk ved at fremstå som et alternativ og et supplement til familieliv og parforhold; to institutioner, der er set som grundsten i vores samfund (Bech 1999:66-7; Politiken 24.4.99, 1. sektion:6). Her i begyndelsen af det 21. århundrede er samfundets holdning til denne livsstil og seksualitet dog præget af større tolerance og frisind end tidligere (Bech 1997:198-206).

Bylivets muligheder er ikke ubegrænsede. Der er en masse regler og restriktioner for vores handlinger og tilstedeværelse i byen givet ved den måde, hvorpå bylabyrinten omslutter os og strukturerer vores færden. Men vi er selv med til at bestemme, i hvilken retning og hvordan vi vil bevæge os. Mennesket er positioneret i labyrinten med et kendskab til byens forskellige funktioner. Vi ved nogenlunde, hvor i byen vi skal gå hen for at gøre det, vi har lyst til, men trods forudsigeligheden kan der i den æske, vi allerede befinder os i, gemme sig en mindre og endnu mere hemmelig æske, og for at finde ud af det må vi udforske den æske - det rum - vi opholder os i.

De rum, der er i fokus i denne artikel, er de såkaldte queerrum. De er en del af byens seksuelle organisering. Jeg har undersøgt queerrum i forbindelse med et studie af det 
samvær, der opstår mellem mennesker, der udfolder deres seksualitet, lyster og nydelser i byrum, hvor der foregår cruising ${ }^{1}$ og seksuelle aktiviteter mellem mennesker af samme køn og mellem mennesker, der seksuelt dyrker fetichisme og sadomasochisme (Christensen 2001). Den teoretiske del af det studie består af et queerteoretisk perspektiv med Steven Seidman, Judith Butler, Eve Sedgwick og Gayle Rubin som eksponenter samt kritisk teori, som Frankfurterskolen og navnlig Theodor W. Adorno, Walter Benjamin og Siegfried Kracauer står for. Desuden bygger studiets teoretiske ræsonnementer på Michel Foucaults diskursive perspektiv. Den empiriske del af studiet baserer sig på feltarbejde og kvalitative interviews. Feltarbejdet er gennemført til Manifests fetichfester, ${ }^{2}$ hvor det er fælles for de mennesker, der kommer, at de seksuelt begærer specifikke tøjmaterialer som eksempelvis latex, læder, pvc, gummi og lingeri samt specifikke genstande som piske, dildoer, håndjern og sko. Desuden er feltarbejdet udført på tre gaysteder, Pan, Heaven og Cosy Bar, der er rum for hovedsageligt homoseksuelle mænd. Feltstudiet er gennemført i perioden december 2000 - november 2001. Endelig har jeg lavet interviews med syv personer, der kommer i det homoseksuelle og det fetichistiske miljø. ${ }^{3}$

\section{Queerrum}

Queerrum er kendetegnet ved, at mennesker kan udfolde en seksualitet, der inkluderer homoseksualitet, fetichisme og sadomasochisme og er i denne sammenhæng en fællesbetegnelse for fetichrum og gaysteder. ${ }^{4}$ Sammenkædningen af queer og rum er en understregning af samværet i disse rum, hvor queerbegrebet henviser både til en bestemt teoretisk optik på seksualitet og køn og til måder, hvorpå mennesker indretter deres liv, og udfolder sider af sig selv (Christensen 2001).

Min anvendelse af queerbegrebet beror på Steven Seidmans ræsonnementer om, at begrebet queer inkluderer lyster og nydelser, der er marginaliserede og ekskluderede $\mathrm{i}$ såvel den heteroseksuelle som homoseksuelle mainstream og er funderet i bevægelser frem og tilbage mellem diskurser, samfundsmæssige forhold, videnskab, teori, sociokulturelle betydninger osv. (Seidman 1997:261). Queerbegrebet er et opgør med samfundets heteronormativitet, der begunstiger og giver forrang til det heteroseksuelle, monogame parforhold som en normalitet og en samfundsinstitution, hvorudfra alle andre former for seksualitet afledes og defineres som afvigende. Heteronormativiteten udtrykkes gennem en samfundsmæssig matchning af køn og seksualitet, hvor mænd udfolder en mandlig identitet og har sex med kvinder, og kvinder tilsvarende udfolder en kvindelig identitet og har sex med mænd. Mand og kvinde er gjort til to ufuldstændige halvdele, der kun kan blive til et hele ved at indgå i et forhold til hinanden (Rubin 1975:179-80). Manden er den seksuelt aktive, og kvinden er den seksuelt passive (Rubin 1984:13-16; Butler 1990:30-1).

Queerbegrebet er desuden et opgør med en essentialisering af hetero- og homoseksualitet og er en ikke-essentialiserende betegnelse, der holdes sammen af bevægelserne væk fra de disciplinerende og normaliserende sociale kræfter (Seidman 1997:134-5). Queerbegrebet inkluderer en forskellighed og rummer ingen bestræbelse på at definere eller fastsætte det forskellige (Seidman 1993:133). Derfor kan queerbegrebet være indsigtsfuldt i forbindelse med at belyse menneskers udfoldelser og fortolkninger af seksu- 
alitet og køn, fordi queerbegrebet lægger op til at beskrive, hvordan en udfoldelse sker, og ikke hvorfor den sker. ${ }^{5}$

Når jeg således bruger betegnelsen queerrum frem for eksempel cruisingrum eller gaysteder og fetichrum, er det, fordi jeg med brugen af queerbegrebet tager højde for en forskellighed i menneskers seksuelle lyster, begær, præferencer og nydelser, modsat et begreb om homoseksualitet, der alene inkluderer det seksuelle samvær mellem to parter af samme køn, eller et begreb om fetichisme, der alene inkluderer en seksuel udtryksform. Desuden understreger jeg med begrebet, at denne forskellighed diskuteres ud fra et samfundsmæssigt syn på seksualitet; et syn præget af heteronormativitet.

\section{Queerrums kendetegn}

Queerrum er virkelige og materielle fænomener, og et afgørende element for eksistensen af dem er længsler, fantasier og drømme om at udfolde og udforske sig seksuelt. Disse længsler, fantasier og drømme kan indfries i byen, fordi den er et sted, der fremmer en koncentration af forskellighed og deraf giver en rummelighed i forhold til, hvordan mennesker kan udfolde sig (Sennett 1996:155-7). Det er gennem disse længsler og drømme, at queerrummenes mulighedsskabende stoflighed og fylde kommer til udtryk. Tom fortæller eksempelvis, at han begyndte at udfolde sin fetichside, da han flyttede til byen, noget, han ikke kunne gøre, mens han boede på Sydsjælland:

Da jeg flyttede til København, vidste jeg, at jeg havde en fetichside i mig, og jeg vidste, at jeg fik mulighed for at udleve den side af mig ved at flytte til byen. Jeg har hele tiden vidst, at jeg havde det i mig; allerede som teenager vidste jeg, at jeg kunne lide at have regntøj på. Jeg havde haft gummitøj i rimelig lang tid, inden jeg begyndte at gå til festerne, men så fik jeg også lyst til at se, hvad der skete til festerne. Det er en side af mig selv, som jeg ikke kan ændre på, og det er en del, der ikke er til at undvære.

Tom har siden sine teenageår vidst, at han bliver seksuelt opstemt af at have gummitøj på, men har ikke offentligt kunne finde rum til den form for udfoldelse, før han flyttede til byen. Byen sættes derfor lig med muligheder for at udfolde sin seksualitet på en måde, han ikke turde, og som han længtes efter at kunne gøre i den provinsby, han kom fra.

Den seksuelle organisering og eksistensen af queerrum er ikke kun $i$ byen, men af byen. Denne sondring har Ulf Hannerz indført for at illustrere, at det sociale samvær ikke kun finder sted $i$ byen, men også finder sted på grund af byen (Hannerz i Bech 1999). Hannerz fremhæver, at nogle former for samvær kun kan finde sted i byen med dens muligheder og faciliteter, som følge af mængden af fremmede mennesker, anonymiteten, pluraliteten, de kortvarige møder og udskifteligheden i relationer. Disse overvejelser har Jacob Haff (1991) også i sit studie af byens erotiske oaser, hvor han argumenterer for, at det samvær, der foregår på disse oaser, muliggøres på grund af byen, og fordi de mennesker, der lever i den, tilpasser sig og udnytter de muligheder for samvær, der er i byen. På den måde understreger Haff, at de erotiske oaser, ud over at de frembringes af byen, også frembringes af de bymennesker, der kommer på oaserne, og som er vant til at bruge byen - i dette tilfælde - som et seksuelt reservoir. Tilsvarende er queerrum tilvejebragt $p a ̊$ grund af både byens faciliteter og de mennesker, der er vant til at bruge og at færdes i byen. 
Samværet i queerrum bygger på afgrænsede menneskelige interaktioner, hvor mennesker finder sammen på grund af fælles lyster, interesser, begær og nydelser i såkaldte temporære interessefcellesskaber eller valgte stammer, som Michel Maffesoli (1996) karakteriserer dem. I stammen styrkes de indre bånd, og medlemmerne beskytter sig selv som stamme mod det udenfor. Der udvikles en fortrolig viden og koder, således at medlemmer kan genkende hinanden, hvorigennem samhørigheden bekræftes (Maffesoli 1996:72-103). Stammerne i queerrum er ikke afgrænsede i forhold til en identitet, men ud fra en identifikation af relationer mellem mennesker. Det vil sige ud fra en identifikation af seksuelle relationer, der inkluderer homoseksualitet, fetichisme og sadomasochisme, og heri er der tale om en social afgrænsning af queersamværet. Der udvikles et fællesskab, der som det primære fællestræk har at udfolde sin seksualitet, lyster og begær uden hensyntagen til eksempelvis hinandens socioøkonomiske status. Det er et fællesskab, hvor vi ikke behøver at kende hinandens baggrunde og øvrige liv. Vi kan mødes om nuet, og de aktiviteter, vi indlader os på, kan holdes adskilt fra det liv og de kontakter, vi har uden for queerrummet. Således præges queersamværet af en form for ikke-målrettet væren, eftersom det primære er at være sammen. Samværet er ikke forankret i, at man skal være noget for hinanden, men derimod i, at det har en værdi i sig selv at være sammen med andre mennesker, man deler noget med for en tid.

Queerrumstammerne opstår som en del af byens dynamik i forbindelse med de muligheder, der er til stede for at udfolde, udforske og indfri seksuelle lyster og nydelser gennem at leve i mængden af mennesker og stimuli. Byens koncentration af stimuli er med til at skabe en øget individualisering og giver mennesker mulighed for at fokusere på hinandens ydre tegn og signaler. Denne fokusering indoptages som måder, hvorpå vi kan udskille os i stammer ud fra specifikke interesser eller præferencer, som eksempelvis seksuelle præferencer, i form af fx tøj, stil, mimik og blik. I denne udskillelse, der foregår i interaktionen mellem mennesker, er der både en nærhed og en afstand, der medvirker til, at vi kan forholde os overfladisk, anonymt og flygtigt til hinanden, samtidig med at vi for en stund kan indgå i en intim, seksuel relation til hinanden.

Maffesolis stammebegreb indfanger et væsentligt aspekt ved eksistensen af queerrum: det er bekvemt, fordelagtigt og behageligt at udfolde sig på måder, der finder genklang hos de øvrige tilstedeværende. Afgrænsningen af queersamværet i forhold til andre former for samvær er med til at skabe queerrum som en del af byens seksuelle organisering. I denne afgrænsning indgår eksklusionsprocesser og normaliseringsteknikker.

Eksistensen af queerrum skal ses i lyset af, at den seksuelle udfoldelse, der finder sted, er afgørende forskellig fra en heteronormativ fortolkning af seksuel udfoldelse. En forskel, der kan have negative konnotationer, og som kan være med til at kanalisere queerudfoldelsen til bestemte byrum på grund af nødvendighed og samfundsmoessige begrcensninger for menneskers udfoldelsesmuligheder. Eksempelvis giver interviewpersonen Mads udtryk for, at det at udtrykke sig seksuelt og kropsligt for ham ofte varierer med den kontekst, han befinder sig i, og de personlige erfaringer, han har med negative og ubehagelige reaktioner fra forbipasserende:

Jeg havde scoret en fyr på Pan, og vi aftalte at tage hjem til ham. Da vi er kommet ud fra Pan, leder vi febrilsk efter en taxi, og der kommer bare ikke nogen. Vi er jo vildt tændte og vil bare hjem og have sex, så vi kysser ret meget, mens vi leder efter en taxi, og lige pludselig går det op for mig, at vi er kommet langt væk fra Pan, og vi kysser stadig. 
Heldigvis var det midt på natten og bælgravende mørkt, men vi lagde alligevel en dæmper på os selv, indtil vi sad i taxien og var på vej hjem til ham.

Mads' forsøg på at undgå, at forbipasserende ser ham udfolde sig homoseksuelt, kan forstås ud fra George H. Meads begreb om den generaliserede anden, der refererer til samfundsmæssige normer og værdier (Mead 1974:154-64). Den generaliserede anden er en forestilling om, hvordan andre mennesker vil reagere på vores adfærd og udtryksformer, og som indebærer en projektion af denne forestilling over på os selv og vores adfærd. Når Mads tænker over, hvor i byen han kysser en anden mand, hænger det sammen med hans forventninger om, at forbipasserende vil reagere negativt på at se to mænd kysse hinanden. Lignende forventninger om negative og ubehagelige reaktioner har Lise i forhold til at udtrykke sin kvindelighed og seksualitet i byen. Lise fortæller:

Når jeg går i byen, går jeg meget diskret klædt. Jeg fremhæver ikke noget ved min figur, der kunne gøre den potentiel fræk, for jeg gider ikke at have alle de dumme blikke og tilråb.

Disse oplevelser af, at visse former for seksuel udfoldelse og adfærd ikke kan finde sted hvor som helst i byen, må sættes i relation til, hvordan byen er organiseret, og at byen sammen med sociokulturelle, økonomiske og politiske kræfter skaber og genskaber relationer, som mennesker indgår i. Byen har karakter af at være en fremtrædelsesform for samfundsmæssige forhold, der regulerer menneskers bevægelsesmønstre og udfoldelsesmuligheder (Simmel 1969:47-9). Samfundet er grundlæggende heteronormativt organiseret, og mennesker er placeret i forskellige udgangspositioner og med forskellige muligheder for at udfolde deres køn, seksualitet, lyster og nydelser (Graham 1998; Seidman 1993, 1997; Sedgwick 1990; Butler 1990, 1993; Rubin 1984). Byen er et rumligt udtryk for denne organisering og begunstigelse, og samfundsmæssige hegemoniske kræfter er med til at strukturere byen ud fra et heteronormativt organiseringsprincip. Holdninger til seksualitet viser sig blandt andet ved ideologiske begrænsninger for menneskers seksuelle udfoldelsesmuligheder, og ideologi er en vigtig konstitutionsfaktor for vores bevægelsesmønstre i byen. Holdninger kommer forskelligt til udtryk som eksempelvis ved, at Københavns Kommune har gjort Ørstedsparken ${ }^{6}$ til et familie- og børnevenligt område ved at skære buske og buskadser ned og ved at gøre parken åben i forhold til beplantning. Disse børnefamilievenlige hensyn kan ses som et udtryk for en ideologi, der sætter restriktioner for, hvor langt en cruising mellem mænd, der udfolder sig homoseksuelt, kan strække sig, og hvor konsekvenserne er, at det bliver sværere for homoseksuelle at bevare parkens funktion som et cruisingsted (Panbladet 12. februar 2001). Byplanlægning, normer og strukturer påvirker, hvordan vores kroppe positioneres og bruges i byrummet (Grosz 1995:108).

Med oplevelser som Mads' og Lises knyttet til det at udfolde sig seksuelt i det åbne byrum træder fetichrum og gaysteder frem som alternative udfoldelsesrum for mennesker, der udfolder sig queer og af den grund kan risikere at blive mødt af negative og ubehagelige reaktioner fra forbipasserende. Lise fortæller her om forskellen mellem det store åbne byrum og fetichrummet:

Det er noget med, at det er legalt at se fræk og sexet ud i det rum, uden at der er nogen, der vender sig om og siger, at man er en billig tøs. Tøjet sætter endnu en ramme, der 
forstærker den ramme, som rummet sætter. Og opmærksomheden, jeg får i fetichrum, håndterer jeg anderledes end i resten af byrummet. I fetichmiljøet kommer opmærksomheden langt mere af beundring, hvor den ude i byen kommer af en liderlig pik. Man ved naturligvis ikke altid, hvad der ligger i hvad, men man kan se det på den måde, folk kigger, og deres ansigtsudtryk. Det er lige så meget andres indstilling til, hvad man laver, der bliver vigtig for den, jeg er.

Modsætningsforholdet mellem queerrum og resten af den heteronormativt organiserede by kan begrebsliggøres med Foucaults heterotopologi (Foucault 1986). Queerrum fungerer som heterotopier, der netop har den specielle egenskab, at de samler mennesker, fordi de afviger i forhold til den samfundsmæssigt påkrævede adfærd og norm. Det er rum, der er relateret til alle andre rum ved deres anden type af samvær, idet de mennesker, der opholder sig i disse rum, har ønsker og forestillinger, der ikke kan indfries andre steder. Der er knyttet en oplevelse af nødvendighed til disse rum på grund af frygt for stigmatisering og sanktionering som reaktion på en homoseksuel, fetichistisk eller sadomasochistisk seksuel udfoldelsesmåde. Mads’ udtalelse fra før signalerer denne nødvendighed, og den understreges af Inge:

Når det går op for én, at man tilhører en seksuel gruppering, er der noget vigtigt $\mathrm{i}$ at konstatere, at man ikke er den eneste, og at man ikke er syg i hovedet. Og så er det godt at finde et sted og se, at der er 1000 andre, der seksuelt tænder på det samme som mig.

Queerrum reflekterer det heteronormative byrum i den forstand, at det findes i queerrum, men det er vendt på hovedet. Der er tale om et kontrastforhold mellem det heteronormative byrum og queerrum, der på den måde er modpol til resten af samfundet. I den henseende har queerrum en yderligere funktion ved at have en kompensatorisk karakter, idet der med queerrummet skabes nogle rammer, hvori et veldefineret socialt samvær kan udfoldes uden af den grund at afføde negative og ubehagelige reaktioner (Foucault 1986:27).

\section{Typer af queerrum}

Rum skabes og genskabes ved menneskers kontinuerlige bevægelser og handlinger, og de afgrænses af menneskelig interaktion og samværsformer (Foucault 1986:23-4). Åbenbare heteronormative rum kan transformeres til queerrum ved eksempelvis, at en gruppe fetichister rumligt manifesterer sig selv:

Jeg sad i S-toget, da en gruppe på 8-10 fetichister steg ind i min vogn. Med det samme tiltrak de sig en masse opmærksomhed. Én af dem var en mand iklædt en militæruniform, og som konstant svingede med sin ridepisk, en anden var en mand i lædertøj, og en tredje var en kvinde i en lakkjole, netstrømper og høje stiletter. Alle var i festhumør og opstemte, hvilket en ung spejder fik at føle. Kvinden i laktøjet begyndte nemlig højlydt at fortælle sine venner om, at hun altid havde fantaseret om at skulle være sammen med en spejderdreng og dominere ham, og midt $i$ hendes detaljerede beskrivelser rejste den unge mand sig og stillede sig ud i midtergangen; beskrivelserne blev tydeligvis lidt for meget for ham. Alt imens dette skete, gik manden i militæruniformen blot frem og tilbage i vognen og så meget myndig og barsk ud. 
Transformeringen af det heteronormative S-togsrum sker ved, at det tilføres en alternativ læsning, der kan finde sted, fordi det aldrig er simpelt eller selvindlysende, hvad et rum kan og består i, men det er heller ikke fuldstændigt uigennemsigtigt (Lefebvre 1991:320-1).

Den måde, som den alternative læsning frembringes på, kan illustreres med en metafor om Dorothys hund Toto fra filmen The Wizard of Oz (Graham 1998:105-6). I slutningen af filmen trækker Toto gardinet fra, for at vi kan se, hvad der er bagved, og hvordan virkeligheden er gjort. Ved at trække gardinet fra hjælper Toto os med at finde ud af, at det ikke er en egentlig troldmand, der bor i slottets hjerte, men i stedet en gammel mand, der er et bifænomen i de handlinger, der foregår. På samme måde er der ikke nogen essentiel heteroseksualitet i seksualitetens hjerte. I S-toget laver gruppen af fetichister et ,spectacle“ ud af sig selv. Derved fremtvinger de en queerlæsning og transformerer en åben heteronormativ kontekst til en queerkontekst. Det er en transformering, der kan hænge sammen med et ønske om og en længsel efter at begære, i dette tilfælde fetichistiske lyster og nydelser, som kan være fraværende i et heteroseksuelt rum. Et begær efter det fraværende kan tilskynde alternative læsninger af et rum (Graham 1998:105-6). Den mekanisme kan ligeledes beskrive de spontane queerrum, der kan opstå i fx fitnesscentre, hvis der er et fravær af homoseksuelle lyster og nydelser. Det fravær kan tilskynde mænd, der udfolder sig homoseksuelt, til at transformere konteksten til en queerkontekst ved at lokalisere andre mænd, der også udfolder sig homoseksuelt. En lokalisering, der kan ske ved, at en lighed genkendes ved tøj, gestus og sprog, der sjældent bliver opfattet og fortolket som indikatorer på homoseksualitet af den heteroseksuelle mand eller kvinde, fordi en identificering af homoseksualitet ikke er relevant eller nødvendig for dem (Painter i Valentine 1996:150).

Queerrum kan også have en mere permanent karakter ved at være etablerede rum som fetichrum og gaysteder, hvor den form for seksualitet, den brug af kroppe, de nydelser og de begær, der er til stede, er grund til overhovedet at komme i disse rum. Samtidig kendetegnes disse rum ved, at der er et alment kendskab til, at de indeholder et queersamvær, således at det kendskab rækker videre end til blot de mennesker, der kommer i sådanne queerrum. Dermed kendetegner det også disse mere permanente queerrum, at en queerlæsning - en transformering af en heteronormativ kontekst til en queerkontekst - forbliver over en længerevarende periode.

\section{Længsel efter et queerrum}

Queerrum er placeret i et skisma mellem begrænsninger og muligheder. For nogle mennesker kan deres færden i queerrum være udtryk for, at queerrummet er endnu et rum, hvori de kan udfolde sig seksuelt, mens queerrum for andre mennesker opleves som et nødvendigt rum, fordi de føler, at de ikke kan udfolde sig seksuelt andre steder. Oplevelser af, om queerrum er en nødvendighed eller en mulighed, hænger sammen med oplevelser af, om queerrum er et oppositionelt eller et sidestillet livsrum til de øvrige, vi opholder os i. Sådanne oplevelser kommer blandt andet til udtryk i, om mennesker er hemmelige eller åbne angående det at komme i queerrum.

Hemmeligholdelse og åbenhed omkring menneskers brug af queerrum hænger tilsyneladende sammen med flere faktorer såsom oplevelser af omgivelsernes reaktion og syn 
på det sociale samvær i queerrum, menneskers indretning af deres liv, hvor længe de har frekventeret queerrum, hvilke motiver de har for at komme samt deres involvering i de tilknyttede miljøer.

For Lise og Tom er der tale om, at queerrummet er en oppositionel verden. Ingen af dem er åbne om, at de igennem de seneste år er kommet i disse miljøer. Få mennesker i deres vennekreds ved, at de seksuelt dyrker fetichisme og sadomasochisme. For dem drejer det sig om, at den måde, de udfolder sig på til fetichfester, står i skærende kontrast til, hvordan de i øvrigt udfolder sig. Lise fortæller:

For mig er det et frirum, der er et modstykke til resten af mit liv. Det er et pusterum, hvor man kan lege lidt. For mig er der en meget stor frihedstrang forbundet med at være i de rum, og de uskrevne regler og normer kan man gøre lidt mere fleksible, uden at det generer andre. For mig er de to verdener klart adskilte, fordi man kan få lov til at give udtryk for nogle sider af sig selv, som man ellers ikke kan gøre i det daglige liv. Der er nogle anderledes rammer, der gør, at man kan give dem et andet indhold end det indhold, der præger ens hverdag.

For Tom og Lise har det også betydning, at rammerne er veletablerede, og at der er konsensus om den type af samvær, der foregår. De har ikke noget alibi, men til gengæld kan de være ret sikre på, at de mennesker, som kommer i fetichrummene, er der af samme grund som de selv. Desuden er Tom og Lise også personer, som uden for queerrummene falder i med den heteroseksuelle kontekst, de befinder sig i. Med et Goffmansk udtryk er der tale om, at de passerer uden for queerrummet (Goffman 1963:72-91), idet der ikke er noget i deres handlinger, der signalerer en queerudfoldelse. Deres bestræbelser på at passere i byen i øvrigt er med til at understrege den markante grænsedragning, de iværksætter mellem queerrum og øvrige byrum.

Eksisterer rummet mere sidestillet til personernes øvrige liv, forekommer rummet i højere grad at være endnu et sted at kunne udfolde sig, om end cruising og seksuel udfoldelse bliver endnu tydeligere og mere markant i queerrummet end udenfor. Inge og Kurt kommer til fetichfesterne, fordi det er rum med nogle andre udfoldelsesmuligheder sammenlignet med S/M-rum og de øvrige byrum. De er forholdsvis åbne om deres brug af queerrum, hvilket blandt andet hænger sammen med, at mange af deres venner også kommer i fetichmiljøet. For Lotte er der også tale om en vis sidestilling mellem queerrum og hendes øvrige livsrum. De forskellige livsrum overlapper hinanden, og Lotte træder konstant ud og ind af dem. Lotte er i det hele taget meget åben om sine queerudfoldelser, hvilket blandt andet hænger sammen med, at hun er aktiv i fetichmiljøet, idet hun debatterer og skriver indlæg om seksuelle temaer.

Denne dikotomi mellem hemmelighed og åbenhed er relateret til at betragte queerrum ud fra både nødvendighed/begrænsninger og muligheder. Når mennesker holder skjult, at de kommer i queerrum, kan det hænge sammen med, at de oplever, at queerrummene er de eneste rum, hvor de kan udfolde deres queerlyster og -nydelser uden at føle sig stigmatiseret og set ,skævt“ til. Dermed har den type rum en oppositionel karakter. Således kan samværet og personers tilstedeværelse i queerrummet få karakter af at være oppositionelt til resten af deres hverdagsliv.

Omvendt når personer er mere åbne om, at de kommer i queerrummene, betragter de queerrummene som sidestillede livsrum til de øvrige, om end med en bevidsthed om, at samværet i queerrum står i et modsætningsforhold til øvrige byrum. De mennesker, 
der er åbne om at komme i queerrum, tillægger grænsedragningerne mellem queerrum og andre byrum mindre betydning i forhold til, hvordan de omgås deres egne seksuelle udfoldelsesmåder. Der er således også tendenser, der peger i retning af åbenhed, og mod at grænserne mellem queerrum og andre rum ikke er stærkt optrukne, men kan overskrides. Tendenser til åbenhed og flydende afgrænsninger af queerrum peger i samme retning, som de resultater Henning Bech peger på i sine studier (Bech 1997:198-9). Bech fremhæver, at det tidligere antagonistiske forhold mellem homoseksualitet og heteroseksualitet ikke længere har samme betydning, blandt andet fordi den måde, homoseksuelle lever på, i stigende grad også kan findes blandt heteroseksuelle. I det omfang der er overlap og fællestræk mellem livsformer på tværs af seksuelle udfoldelser, er det forventeligt, at det også udtrykkes ved, at de rum, hvori queerudfoldelser finder sted, ikke er hermetisk omsluttet af hemmeligholdelse, skjul og fortielse.

\section{Det private, offentlige queerrum}

Queerrum er offentlige rum, men de fremstår ikke som entydige offentlige rum. Der er en gruppe mennesker, der koncentrerer sig i disse rum og tager dem til sig som deres egne. Dette fænomen, at offentlige rum får tillagt „ejendomsrets“-betydninger i form af at tilhøre bestemte grupper af mennesker, har blandt andre Sheri Cavan (1963) studeret. Hun har undersøgt interaktioner mellem en gruppe aktører, der har defineret et rum som deres, og aktører, der træder ind i disse rum uden at have et tilhørsforhold til rummet. Cavan har indført begrebet hjemmeterritorier til at forstå dette fænomen.

Det mest genuine hjemmeterritorium er det private hjem, hvortil der er en meget begrænset adgang, og aktiviteter, der offentligt enten er ulovlige eller medfører stor ydmygelse, kan uden videre finde sted hjemme. Offentlighedens moral, værdier og normer tages ikke nødvendigvis med ind i hjemmet. Hjemmet har også en familiaritet over sig, og forandringer i hjemmet foretages kun af én selv. Således tilskynder hjemmet modsat offentlige steder en fornemmelse af intimitet og kontrol (Cavan 1963:17-18). Offentlige steder kan imidlertid undergå en transformering i retning af at blive et hjemmeterritorium for bestemte grupper af mennesker. Det kan eksempelvis være private klubber, hvor der er restriktiv adgang, og er man ikke en del af gruppen, kan man kun inviteres ind som deltager.

Queerrum har karakter af at fungere som hjemmeterritorier. Hvad angår fetichfester, skal festdeltagerne være medlemmer af Manifest. Denne betingelse har to formål. Det ene er af hensyn til politivedtægten, der tilsiger, at fetichfesterne skal være lukkede fester, for at der må være et darkroom. Det andet formål hænger sammen med, at fetichrum derved gøres til et rum for en bestemt gruppe mennesker, så mennesker ikke bare kan gå ind fra gaden og deltage. Den lukkede fest skaber konsensus om, hvorfor man er til stede. På den måde reduceres en tilgængelighed med det til følge, at fetichrummene territorialiseres.

På gaystederne er der ingen krav om medlemskab; man kan gå direkte ind fra gaden. Der er dog ingen tvivl om, at Pan, Heaven og Cosy Bar er gaysteder, hvilket signaleres med koncentrationen af mænd og den fysiske udsmykning, som på Heaven klart signalerer homoerotik. Der er bowlerne på bardisken med glidecreme og kondomer, som meget sjældent vil kunne findes på en heteroseksuel café eller et diskotek. Disse kraftige sig- 
naler om, at Pan, Heaven og Cosy Bar er gaysteder, er med til at gøre dem til hjemmeterritorier og til at vise omgivelserne, hvilken gruppe disse steder domineres af og tilhører.

Karakteren af queerrum som hjemmeterritorier for en gruppe mennesker indikerer, at der er en lokal privathed over disse offentlige rum, samtidig med at der er en tilknyttet familiaritet og intimitet. Det vil sige, at queerrummene har karakter af at være en mellemting mellem det store komplekse og organiserede byrum og det private rum med de nære og intime relationer. Queerrum er indbefattet af bymæssige fænomener som anonymitet, civil uopmærksomhed, koncentration af fremmede og blaserthed. Men queerrum er også præget af nære relationer - ikke i traditionel forstand - men i den forstand, at deltagere udfolder deres lyster og nydelser blandt mængden af fremmede mennesker, som eksempelvis denne festdeltager til en fetichfest gør:

På dansegulvet danser en kvinde alene. Hun har en hvid gummisygeplejerskeuniform på. Midt i dansen tager hun uniformen af, og hendes underliv er udækket. Hun finder sin ridepisk frem, og med den går hun i gang med at tilfredsstille sig selv.

Deltagere kan indgå i seksuelle relationer, og hovedparten af de mennesker, de omgiver sig med, forbliver fremmede, fordi de ikke opnår noget kendskab til, hvem de andre er, hvad de laver, deres politiske holdninger, deres familierelationer osv. Men deltagerne forbliver ikke fremmede for hinanden, idet alle deler en fælles lyst til at udfolde deres seksuelle lyster og nydelser, som det fremgår af denne observation:

Festen har været i gang i nogle timer og er ved at nå højdepunktet. Der er kommet gang
i en større sexseance på ét af billardbordene i playroom'et, og deltagerne begynder at
stimle sammen. Der ligger en kvinde på ryggen, og hendes arme og ben holdes fast. Der
er to kvinder, som aer og kysser hendes overkrop, alt imens de selv bliver spanket,
slikket og penetreret bagfra af to mænd. Kvindens underkrop stimuleres af en kvinde og
mand, ved at de slikker og penetrerer hende, og manden varierer mellem at stimulere
de to kvinder, om end det mest drejer sig om kvinden på billardbordet. Da kvinden på
billardbordet næsten er i ekstase og har nået orgasmens højdepunkt, tænder én af
tilskuerne et nødblus og bader seancen i lys.

Således er queerrum på grund af sin karakter som hjemmeterritorium ikke et entydigt offentligt rum, fordi samværet er af personlig og intim karakter. Omvendt er queerrummet heller ikke et entydigt privat rum, fordi samværet består af en mængde fremmede mennesker, man deler et fælles ærinde med. Der sker med andre ord en privatisering af et offentligt rum med det til følge, at det er nemmere for personer i disse rum at løsrive sig fra samfundets normer, værdier, regelsæt samt andres og egen overvågning. I forhold til den tidligere fokusering på queerrum som etableret ud fra både begrænsninger og muligheder kan denne spænding relateres til Cavans betragtninger om hjemmet, det offentlige rum og hjemmeterritorier. Alt samvær i hjemmet er muligt, mens samværet i offentlige rum er udsat for begrænsninger. Med sammensmeltningen af det private hjem og det offentlige rum i form af hjemmeterritorier følger det private hjems muligheder og det offentlige rums begrænsninger. Det vil sige, at hjemmeterritorier er påvirket af både muligheder og begrænsninger. 


\section{En kønnet og seksualiseret offentlig-privat-dikotomi}

Queerrummene redefinerer skillelinjen mellem offentligheds- og privathedssfæren på en måde, der løsriver heteroseksualitet-homoseksualitet-dikotomien og mand-kvindedikotomien fra hinanden og fra offentlig-privat-dikotomien. Inden jeg beskriver, hvordan denne løsrivelse kommer til udtryk, vil jeg først gennemgå, hvordan de tre dikotomier hænger sammen.

Nancy Duncan argumenterer for, at offentlig-privat-distinktionen fungerer som både en kønnet (gendered) og seksualiseret forskel, der genererer og legitimerer et undertrykkelses- og afhængighedsforhold forankret i køn og seksualitet. Idealtypisk er det private sat i relation til hjemmet, familien, ejendom, det personlige og gode liv, begær, seksualitet, omsorg, ulønnet arbejde og reproduktion. Heroverfor er det offentlige idealtypisk set som det kulturelle, det rationelle, borgerskabet, det civile, lov og ret, lønnet arbejde, produktion og stat. Historisk er kønnet blevet knyttet til denne dikotomi, hvor kvinder betragtes som en del af privatsfæren, mens mænd ses som en del af offentlighedssfæren. Ligeledes er seksualitet blevet reguleret $\mathrm{i}$ forhold til denne dikotomi, hvor seksualitet oftest er set som noget, der hører privatsfæren og alene privatsfæren til. Det drejer sig vel at mærke kun om andre former for seksualitet end heteroseksualitet. Mennesker, der udfolder sig heteroseksuelt, kan hele tiden gøre det i offentlige rum uden at møde sanktioner, fordi samfundet er heteroseksuelt organiseret (Duncan 1996:128-30). Det heteroseksuelle par er som en omvandrende reklamesøjle for deres seksualitet.

Offentlig-privat-distinktionen, som en kønnet og seksualiseret forskel, må analyseres ud fra samfundsmæssige forhold og begrænsninger. Det har Bech gjort ved at forsøge at udlægge, hvad denne ulighed er udtryk for. Bech viser, at der er tale om en sammenkædning af maskulinitet og byrum, og han fremhæver, at kvinder ikke på samme måde som mænd har kunnet leve med og i byen. Kvinder er blevet set som marginale personer i bybilledet og har ikke kunnet færdes frit i byen og tage dens muligheder til sig, som mænd og i særdeleshed homoseksuelle mænd gør det. Homoseksuelle har fx i årtier mødtes i parker, på toiletter og i saunaer for at indgå i seksuelle relationer. Det har kvinder uanset seksuel orientering ikke gjort i samme omfang, hvilket blandt andet må ses i lyset af risikoen for vold og overfald, hvis en kvinde forsøger at cruise om natten i en park. Det har ifølge Bech medvirket til, at de kvindelige og mandlige seksuelle udfoldelser har været og stadig er forskellige, men altså forskellige på grund af samfundsmæssige vilkår for mænds og kvinders levemåder og ikke på grund af biologiske forskelle på de to køn (Bech 1997:131-6).

Mine studier af queerrum viser, at der med fetichrum skabes rammer i form af at være hjemmeterritorier, hvor kvinder kan udfolde deres seksualitet i samme udstrækning, som mænd kan, og hvor kvinder føler sig trygge ved at være seksuelle, udfordrende og opsøgende. ${ }^{7}$ Der er ikke noget, der peger på, at kvinder har en mindre seksuallyst eller en mindre udfarende og aggressiv seksualitet, end mænd har. Deltagernes sexkvantitet har ikke noget med køn at gøre, men derimod noget at gøre med den enkeltes sexlyst. I stedet for at betragte køn som en grund til forskellige seksuelle udfoldelser er det snarere nødvendigt at betragte rammerne for den seksuelle udfoldelse som afgørende. De rette rammer for kvinders seksuelle udfoldelser skal være til stede, hvilket er tilfældet, når fetichrum som et hjemmeterritorium fjerner risikoen for vold og 
overgreb samt annullerer sammensmeltningen af en seksuelt udfarende kvinde og luderen/den billige tøjte. Dermed er fetichrummene med til at redefinere kvinders seksuelle tilstedeværelse i det offentlige rum og med til at løsrive sammenhængen mellem kvinde, seksualitet og privatsfære, ved at kvinder i fetichrummene rumligt og offentligt manifesterer sig feminint og seksuelt. Med fetichrummene kan kvinder bruge de muligheder for at indgå i kortvarige, segmenterede seksuelle relationer, der er i byen, og de kan bruge fetichrummene som seksuelle reservoirer. Det vil sige, at der i fetichrum skabes betingelser, der for kvinders vedkommende gør, at de kan udfolde sig på måder, hvortil der kan trækkes en parallel til de måder, hvorpå homoseksuelle i årevis har udfoldet sig på jf. Bechs studier.

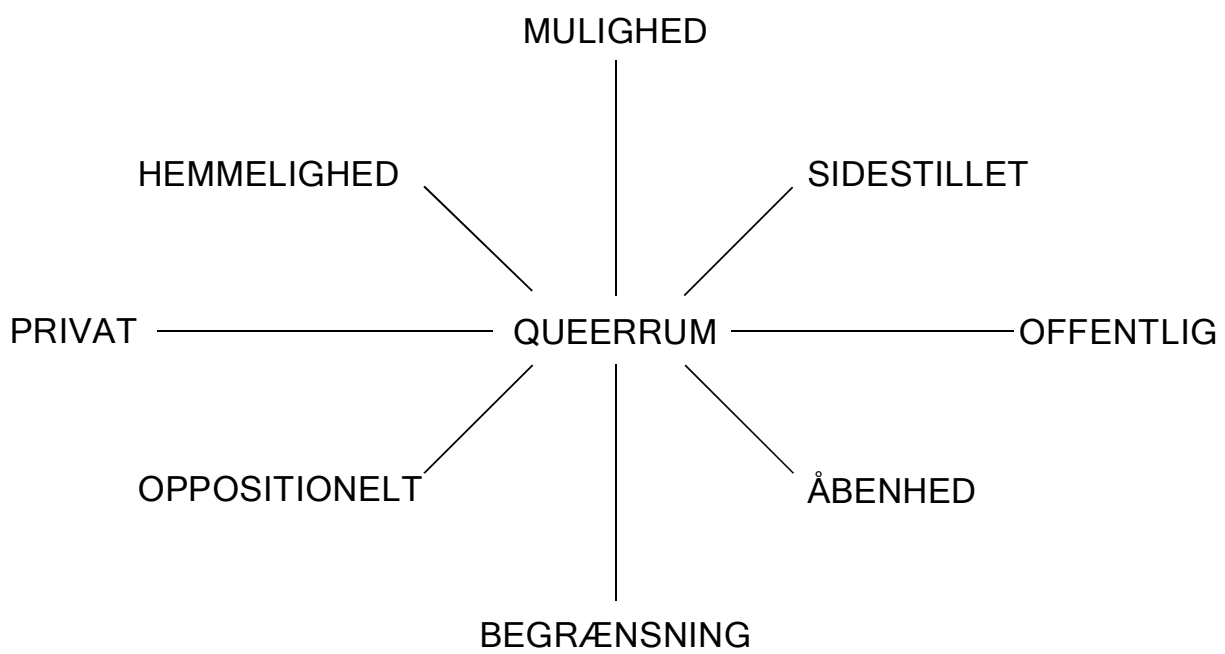

Figur 1. Oversigt over dikotomier, der har betydning for queerrums beståen.

\section{Lysternes byhuler}

I byens sociale samvær florerer forventninger, fantasier, ideer og ønsker mellem hinanden. Dette virvar er minimeret i queerrum, hvor der er skabt en konsensus. I queerrummet ved vi på forhånd, at vi er samlet om at udfolde vores seksualitet, køn og krop samt opnå nydelser og glæder. Der er fælles praksis for samværet og for rummet, der gør, at henvendelses- og samværsformer i vid udstrækning er formet med fællesskabet, således at vi kan træde ind $\mathrm{i}$ en skabelon og udforske den. I nedenstående figur er illustreret de dikotomier, der har betydning for queerrums eksistens og for de kulturelle betydninger, der knytter sig til queerrummene.

Gennem kombinationen af de fire dikotomier, der indvirker på queerrummets udtryksform, tydeliggøres de almene samfundsmæssige forhold. Den samfundsmæssige organisering og ideologisering er tilpas åben og fleksibel til, at queerrum ikke udelukkende står i et opposionelt forhold til resten af byen eller er etableret på grund af 
begrænsninger og hemmeligholdelse. Omvendt er samfundet heller ikke så frisindet, tolerant og liberalt, at queerrum har karakter af blot at være endnu en mulighed for livsudfoldelser eller af at være omgivet af åbenhed og fungere sidestillet med andre livsrum som følge af, at queerudfoldelser frit kan finde sted i det offentlige rum. Queerfællesskabet kan både ses som endnu ét af de fællesskaber, der er tilgængelige i byens mangfoldighed af fællesskabsdannelser, og ses som én af de få muligheder, mennesker kan opleve at have for at udfolde deres homoseksuelle, fetichistiske og sadomasochistiske lyster og nydelser.

De etablerede queerrum er geografisk lokaliserbare rum, og i princippet kunne et queersamvær finde sted i et hvilket som helst fysisk rum; samværet afhænger alene af, hvilken betydning det tillægges af mennesker og af de samfundsmæssige forhold. Queerrum fungerer som huler med den egenskab, at de ikke altid er lige nemme at få øje på. Man skal lede lidt, og man skal udvikle en næse eller en sans for at finde de huler, man kan lide. Huler afgrænser sig ved, at der er nogen, der holdes ude og andre inde, selv om der er bevægelser, der transcenderer grænserne mellem det indenfor og det udenfor. Det er på ingen måder givet, hvem der er inde, og hvem der er ude.

Det er hulens primære funktion at omkranse og lukke sig om én og virke som et værn mod det, der foregår uden for hulen, samtidig med at det uden for hulen værnes mod det, som foregår i hulen. Det er, som Bernadette i filmen Priscilla - The Queen of the Desert siger: „In some strange ways it [the city] takes care of us. I don't know if that ugly suburban wall stops them getting in or us getting out.“

Det samme gælder med queerrum, der ,tager sig af“ de mennesker, der opholder sig i dem, og queerrum fungerer som en rumlig manifestering af et specifikt socialt samvær, der derigennem opnår berettigelse og ly til at udvikle sin egen praksis. Herved fremgår, at queerrum har en specifik funktion for de mennesker, der opholder sig i queerrummet, og at det qua dets funktion som heterotopia kan forstås som en modpol til resten af samfundet. Queersamværet er et valgt fællesskab, der koncentrerer sig om specifikke udfoldelser af seksualitet - lyster og nydelser. Fællesskabet er en bymæssig mulighed, der opstår med de faciliteter, byen skaber med sin differentiering og pluralitet. Det er en bymæssig mulighed, der kan indfri specifikke forventninger til et samvær, og som dermed er en del af byens seksuelle organisering.

\section{Noter}

1. Cruising er af en mere pågående, dristig og fræk karakter end flirt. Når man cruiser et andet menneske, er det oftest med henblik på at opnå en kontakt, der kan lede videre til seksuelle aktiviteter.

2. Manifest er en fetichklub, der arrangerer månedlige fetichfester, oftest forskellige steder i København. På det tidspunkt, hvor jeg gennemførte mit feltarbejde, blev festerne afholdt på Forbrændingen i Albertslund og på Café Central Park i København. I midten af 1990'erne, hvor fetichbølgen for alvor nåede Danmark, var det ofte nye steder til hver fest. Eksempelvis er festerne blevet afholdt under Langebro og på technoklubber i det indre København. For tiden bliver festerne holdt på Level Cph i Indre By.

3. De syv informanter er Lise, Inge, Lotte, Kurt, Tom, Mads og Peter (navnene er fiktive) samt arrangøren af fetichfester, Stig Christensen. Lise er sidst i 20’erne og har igennem de sidste to år deltaget i fetichfester, samtidig med at hun er medlem af Det Sorte Selskab. Inge er sidst i 30'erne og danner par med Kurt, der er i midten af 50'erne. Inge er inden for de seneste to år begyndt at komme i fetichmiljøet og S/M-klubberne. Kurt har det meste af sit voksenliv været bevidst om sine lyster til både fetich og S/M, men har navnlig 
igennem de seneste 10-15 år udfoldet de sider af sig selv. Lotte er sidst i 40'erne og meget aktiv inden for fetichmiljøet. Hun skriver en række indlæg om seksualitet i blandt andet magasiner og har været tilknyttet en butik, der sælger fetichtøj, sexremedier, bøger om seksualitet osv. Tom er sidst i 20 'erne og er, siden han flyttede til København for seks-syv år siden, kommet meget i fetichmiljøet og i S/M-klubber. Peter er først i 30 'erne og kommer meget i homomiljøet sammen med sin partner. Endelig er der Mads, der er sidst i 30 'erne, og som igennem de seneste år er begyndt at komme meget i homomiljøet.

4. Queerrum er dog ikke kun fetichrum og gaysteder, men kan også være andre rum, hvori der forekommer queerudfoldelser. Eksempelvis kan andre queerrum være sexsaunaer og sexbiografer.

5. Jeg betragter queertankegangen som et redskab til at reflektere køn og seksualitet som sociale konstruktioner. Derudover betragter jeg queertankegangen som en praksis, der kan følges af det enkelte menneske til at slippe disciplinerende kræfter løs og ikke lade sig identificere ud fra seksualitet eller køn, men i højere grad udnytte mulige vakuummer, der kan opstå, til at udforske sig selv - ikke med henblik på at finde sig selv, men med henblik på at undgå en kategorisk identifikation. Et eksempel på, hvorledes handlinger kan udsættes for en queering, er en event i regi af AIDS-fonden, der i foråret 2001 arrangerede en Grand Prix Nostalgiaften med henblik på at indsamle penge til aids-relaterede formål. Den ramme var naturligvis med til at skabe en kontekst for de hændelser, der skete. En af kunstnerne var Caroline Henderson, der fremførte „Fly on the Wings of Love“" og fremførte den med et alias, Dolores J. En formodet heteroseksuel kvinde hæftede et dragklingende navn på sig. Til at fremføre sangen var der ud over Carolina Henderson ca. 20 kvinder i sorte bodystockings og netstrømper. De dansede meget seksuelt med hinanden. Carolina Henderson var iført en latexdragt fra hals til fod og sorte vinger og blev båret ind på scenen af en mand i gummidragt $\mathrm{g}$ halsbånd signalerende hans underdanighed. Der skete en queering af sangen i kraft af settingen og kunstnerne, og en sang, der, når den fremføres af Brdr. Olsen, er heteroseksuel om en mands kærlighed til en kvinde, fik en ny betydning, der kunne rumme en seksuel tiltrækning mellem kvinder og mellem en dominatrixkvinde og en underdanig mand. Selve titlen på sangen blev dermed bærer af en alternativ seksuel udfoldelse til den heteroseksuelle udfoldelse.

6. Ørstedsparken er i homomiljøet kendt som et sted, hvor homoseksuelle mænd engagerer sig i forskellige seksuelle aktiviteter.

7. Det er dog vigtigt at være opmærksom på, at de kvinder, der kommer i queerrummet, kan være en speciel gruppe af kvinder. Det påkalder en varsomhed med at betragte disse kvinders seksuelle udfoldelse som dækkende for kvinder generelt.

\section{Litteratur}

Bech, Henning

1997 When Men Meet. Cambridge: Polity Press.

1999 Fritids verden. København: Forlaget Sociologi.

Butler, Judith

1990 Gender Trouble: Feminism and the Subversion of Identity. New York: Routledge.

1993 Bodies that Matter. New York: Routledge.

Cavan, Sheri

1963 Interaction in Home Territories. Berkeley Journal of Sociology 8:17-32.

Christensen, Gunvor

2001 I lyst og nydelse. Et studie af seksualitet og køn i byrum. Københavns Universitet. Sociologisk Institut.

Duncan, Nancy

1996 Renegotiating Gender and Sexuality in Public and Private Spaces. I: Nancy Duncan (ed.): Body Space. New York: Routledge.

Foucault, Michel

1986 Of Other Spaces. Diacritics 16:22-7.

Goffman, Erving

1963 Stigma. Englewood Cliffs, NJ: Prentice Hall. 


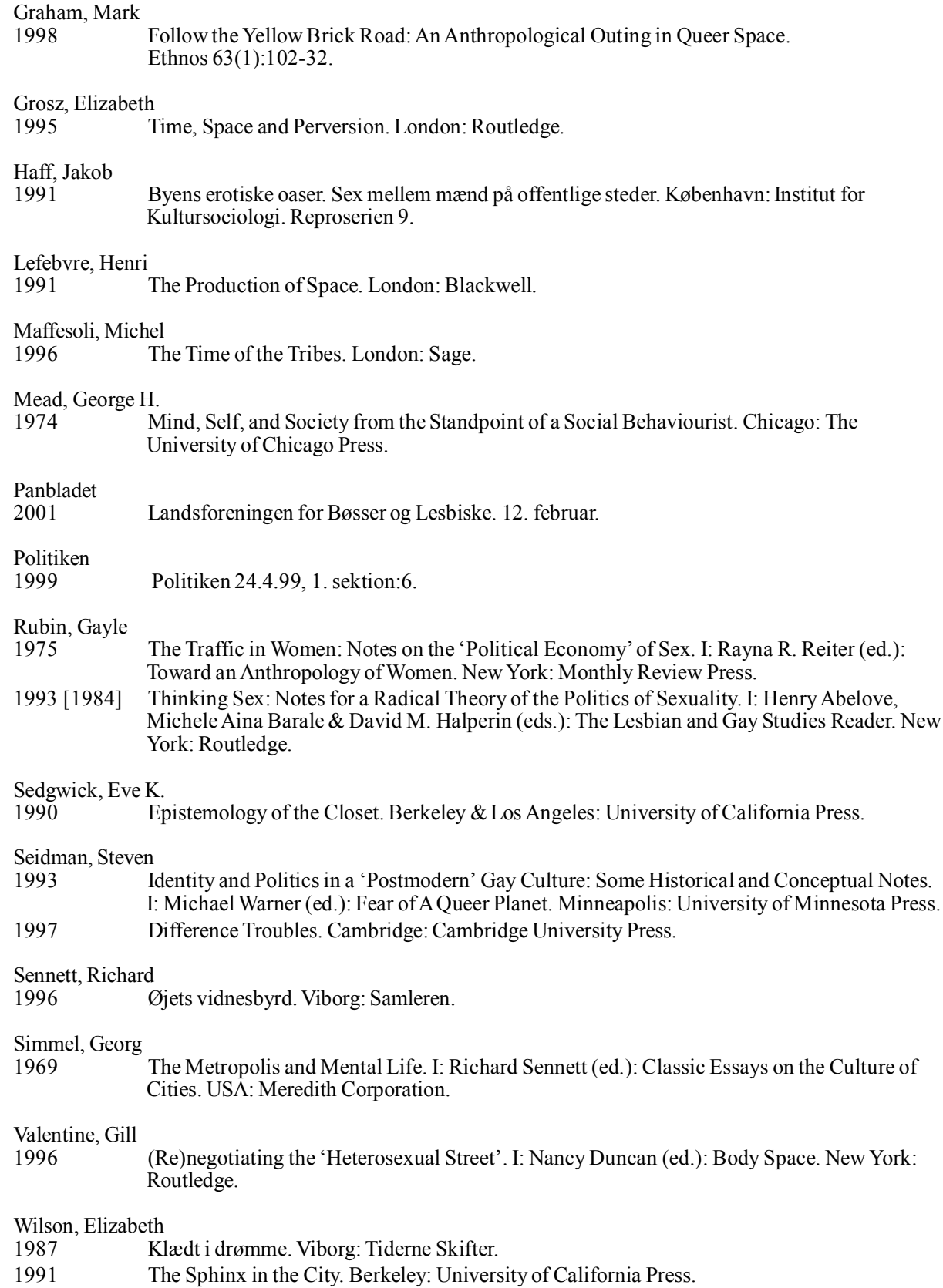


